\title{
The easternmost record of Macratriinae LeConte, 1862 (Coleoptera: Anthicidae), with a new species from Fiji and a genus-rank synonymy in Macratriini LeConte, 1862
}

\section{DMITRY TELNOV ${ }^{1,2,3}$}

${ }^{1}$ Natural History Museum, Department of Life Sciences, Cromwell Road, SW7 5BD, London, United Kingdom.

"=anthicus@gmail.com; @ https://orcid.org/0000-0003-3412-0089

${ }^{2}$ Institute of Biology, University of Latvia, O. Vâcieđa iela 4, LV-1004, Rìga, Latvia

${ }^{3}$ Coleopterological Research Center, Institute of Life Sciences and Technology, Daugavpils University, Vienîbas iela 13, LV-5401, Daugavpils, Latvia

\begin{abstract}
The easternmost record of Macratria Newman, 1838 from Fiji is presented, and M. fijiana sp. nov. is described and illustrated. Biogeographical patterns and diversity of Pacific Macratriinae are briefly discussed. Additionally, a new genus rank synonymy in Macratriinae is proposed: Thambospasta Werner, 1974 syn. nov. of Salimuzzamania Abdullah, 1968. New combination is made for Salimuzzamania howdeni (Werner, 1974) comb. nov. (from Thambospasta).
\end{abstract}

Key words: Macratria, Salimuzzamania, Thambospasta, taxonomy, synonymy, new species, Melanesia, Nearctic Region, Neotropical Region

\section{Introduction}

The Macratriinae LeConte, 1862 is cosmopolitan subfamily of Anthicidae Latreille, 1819 (Werner \& Chandler 1995; Chandler 2002; 2010; Telnov 2011). Macratriinae is currently represented by two tribes, the monotypic fossil Camelomorphini Kirejtshuk, Azar et Telnov, 2008 in Kirejtshuk \& Azar, 2008 (for the monotypic genus Camelomorpha Kirejtshuk, Azar et Telnov, 2008 in Kirejtshuk \& Azar, 2008 from Lebanese amber), and Macratriini LeConte, 1862 (for the extant cosmopolitan Macratria Newman, 1838, the Central American Salimuzzamania Abdullah, 1968 and the Southern U.S. Thambospasta Werner, 1974, of which two latter synonymized in the present paper) (Chandler 2010 in part; Telnov 2012a). Ninety-nine Macratria species have hitherto been recorded from Melanesia, with the easternmost record in the region from the Solomon Islands (Telnov 2011; 2012b; 2017).

Melanesia is a vast area in south-western Pacific, from New Guinea in the West to Fiji in the East. The name for this subregion of the Pacific, first introduced by Dumont d'Urville (1832) and still widely used, does not in fact accurately reflect the prehistory of human populations in the Pacific (Pawley \& Green 1973; Green 1991; Tcherkézoff 2009).

While identifying two historical Macratria specimens from Viti Levu, Fiji's main island, in the Coleoptera collection of the Natural History Museum, London, the surprising discovery was made of the easternmost record of this genus. The new species is described and illustrated here as Macratria fijiana sp. nov. The biogeography and distribution of Macratriinae is briefly discussed.

Additionally, a new genus-rank synonymy is introduced for Central American and southern Nearctic Macratriini.

\section{Material and methods}

For proper examination, the beetles were relaxed in water. Abdomens were detached and cleared for several hours 
$10 \% \mathrm{KOH}$ at room temperature. Genitalia were mounted on microscope slides and fixed in Dimethyl hydantoin formaldehyde (DMHF) to make permanent mounts. For morphological studies, a Leica S6D binocular stereomicroscope was used. Photographs of the adults were taken with Canon EOS 77D camera and Canon MP-E $65 \mathrm{~mm}$ lens, of genitalia and terminal abdominal segments - with Sony Cyber-shot camera mounted to Meiji optical microscope.

Data from all specimen labels are reproduced verbatim, without additions. If not stated, all labels are printed. The authors' supplemental or explanatory comments are placed in square brackets. Labels (if there are multiple labels on a specimen) are separated by a slash. The two studied specimens of the new species are provided with a black-framed label on red paper 'HOLOTYPUS' and 'PARATYPUS', respectively.

\section{Acronyms of the material stores:}

BMNH Natural History Museum (formerly British Museum, Natural History), London, United Kingdom; CNCI Canadian National Collection of Insects, Ottawa, Canada;

DTC Collection Dmitry Telnov, Rīga, Latvia.

\section{Results}

\section{New description}

\section{Macratria fijiana sp. nov.}

(Figs 1-12)

http://zoobank.org/EF47C41D-A1D3-456A-92C7-51C3B795CB03

Material. Holotype $\widehat{\delta}$ BMNH: 14. 2. [19]46. [handwritten] R. A. Lever [printed] Naduruloulou C. [handwritten] Fiji [printed] 1928 [handwritten] / Pres. by Comm Inst Ent B.M. 1981-315. [antennomeres 6-11 of the right antenna and right metatibia- and tarsus are missing].

Paratype 1 [ [BMNH]: R. A. LEVER [printed] C [handwritten] FIJI [printed] 1228 Karova 23.8.[19]41 [handwritten] / Pres. by Comm Inst Ent B.M. 1981-315. [left elytron is missing].

Description. Measurements. Holotype, total length $3.75 \mathrm{~mm}$. Head length without cranial neck $0.7 \mathrm{~mm}$, width across compound eyes $0.61 \mathrm{~mm}$. Pronotal length $0.94 \mathrm{~mm}$, maximum width $0.62 \mathrm{~mm}$. Elytral length $2.1 \mathrm{~mm}$, maximum width $0.95 \mathrm{~mm}$. Paratype is $3.7 \mathrm{~mm}$ long.

Dorsum brown, pronotum darker, head reddish-brown. Mouthparts, antennae and legs yellowish-brown. Venter brown, reddish-brown on head.

Head glossy dorsally, with large, moderately prominent, compound eyes. Interfacetal setae long and dense. Frontoclypeal suture or impression not observed. Posterolateral angles rounded, head base subtruncate, with distinct moderately broad median notch. Punctures on frons and vertex gentle, intervening spaces glossy, same length to $3 \mathrm{x}$ as large as punctures. Setae golden, moderately long, suberect. Several much longer, erect tactile setae around compound eyes and on vertex. Antenna slender, extending slightly over base of elytra. Second antennomere nearly as long as third antennomere. Antennomeres 4-8 long and slender, 9-10 somewhat thickened and slightly widened distally. Terminal antennomere strongly elongate, slightly asymmetrical, obtusely pointed apically, in male distinctly longer than, in female about as long as combined length of antennomeres 9-10. Terminal maxillary palpomere cultriform. Pronotum glossy and flattened dorsally, broadly rounded on anterior margin, gradually constricted laterally towards slightly narrower base. Punctures on pronotal disc rather large, in part coarse on basal one third, intervening spaces glossy, as large as to (generally) narrower than punctures. Setae yellowish, long and dense, appressed. On pronotal disc and along its lateral margins with several much longer, erect tactile setae. Scutellar shield small, truncate apically. Elytra subopaque, flattened dorsally, elongate and slender. Punctures on elytral disc circular, rather large and dense, arranged into 5-6 partially confused longitudinal rows on each elytron. Punctures becoming flat on postbasal half of elytra. Intervening spaces generally as large as punctures. Setae whitish to yellowish, long and dense, appressed. Longer erect tactile setae scattered over elytral disc. Legs with clavate femora. Tibiae covered by long and dense setae. Terminal tibial spurs paired, apically pointed. Male basal metatarsomere longer than 

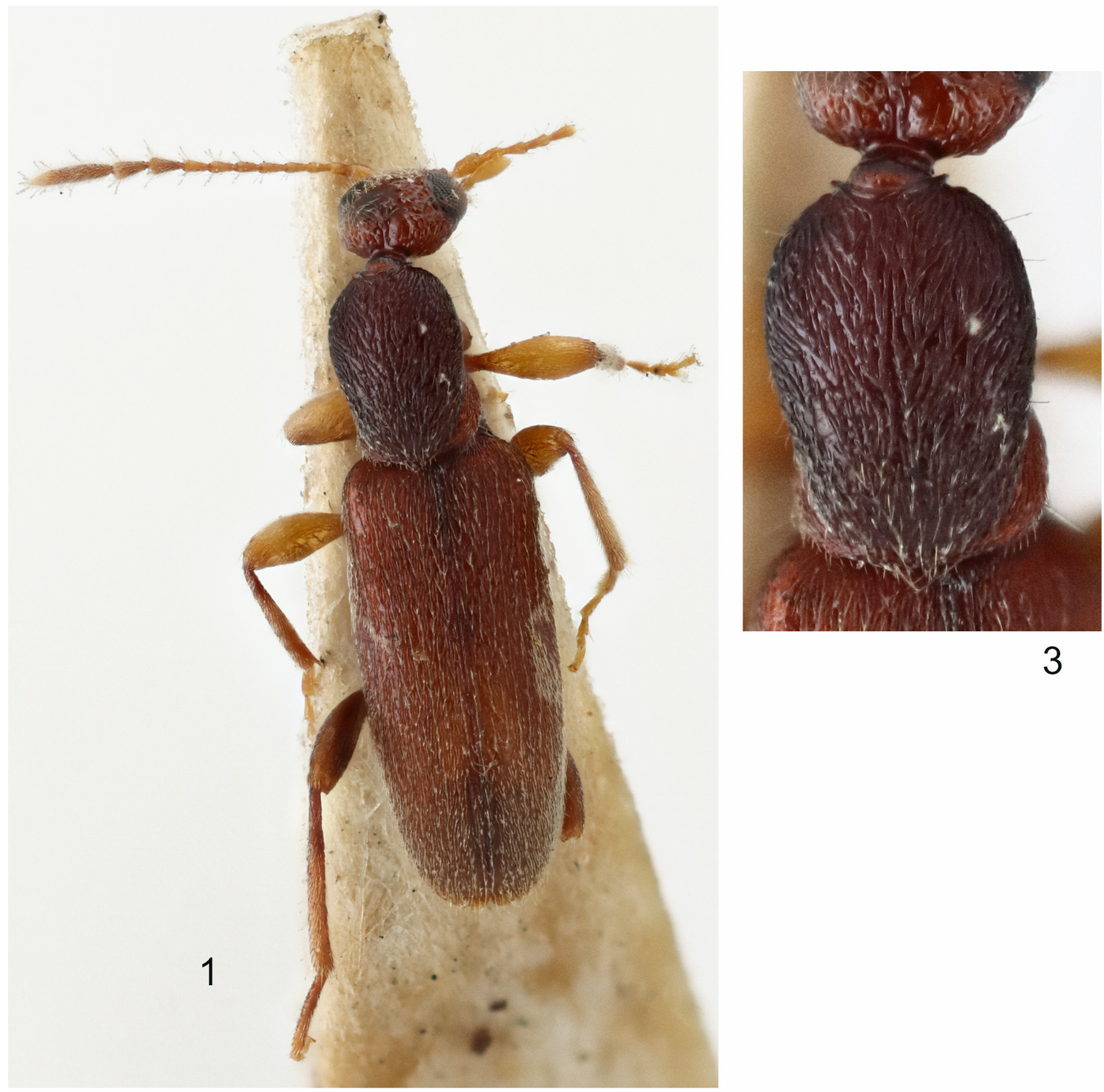

3

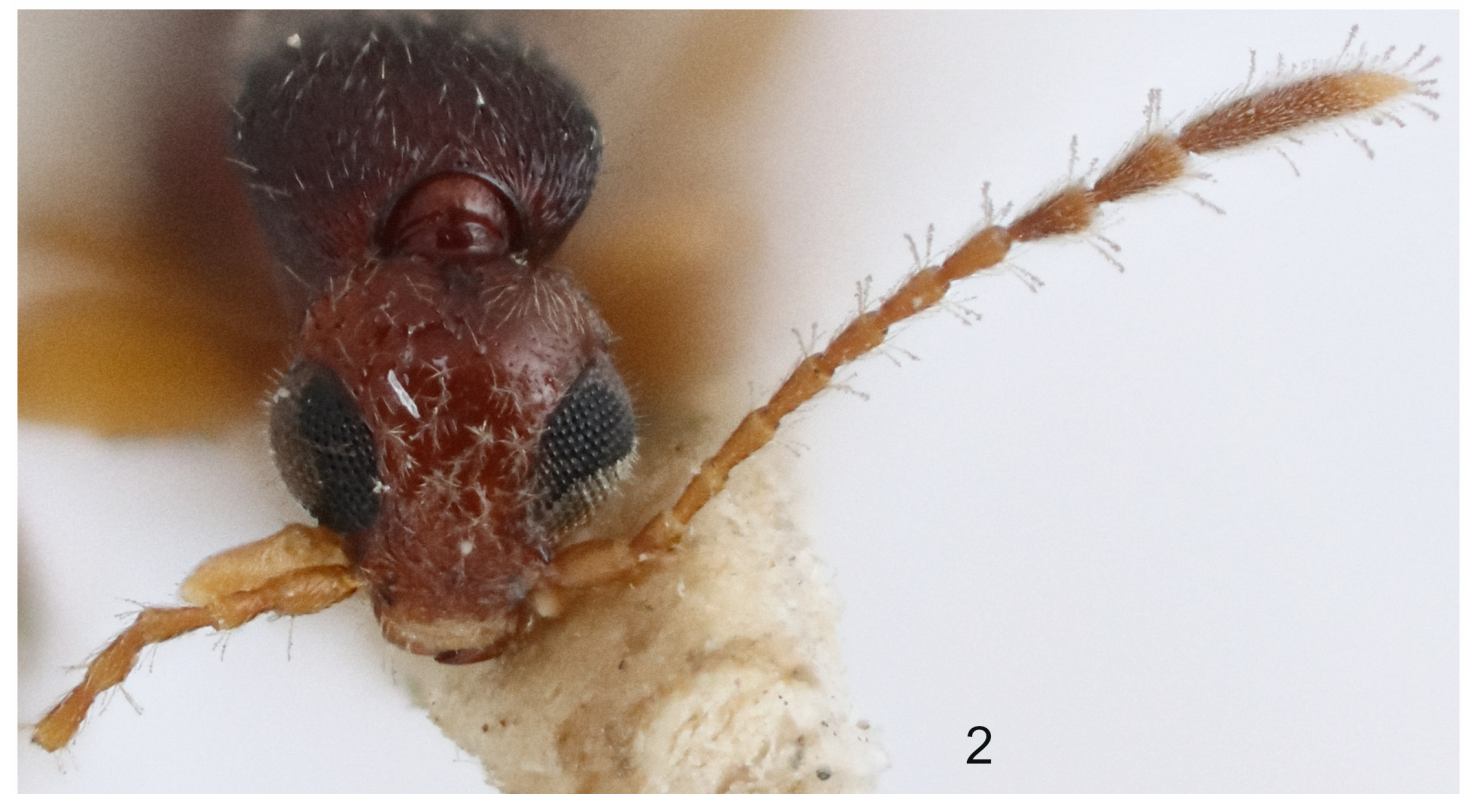

FIGURES 1-3. Macratria fijiana sp. nov., holotype đ̊ (BMNH). 1-general view, dorsally, 2-head, dorsal view, 3-pronotum dorsal view. Not to scale. 

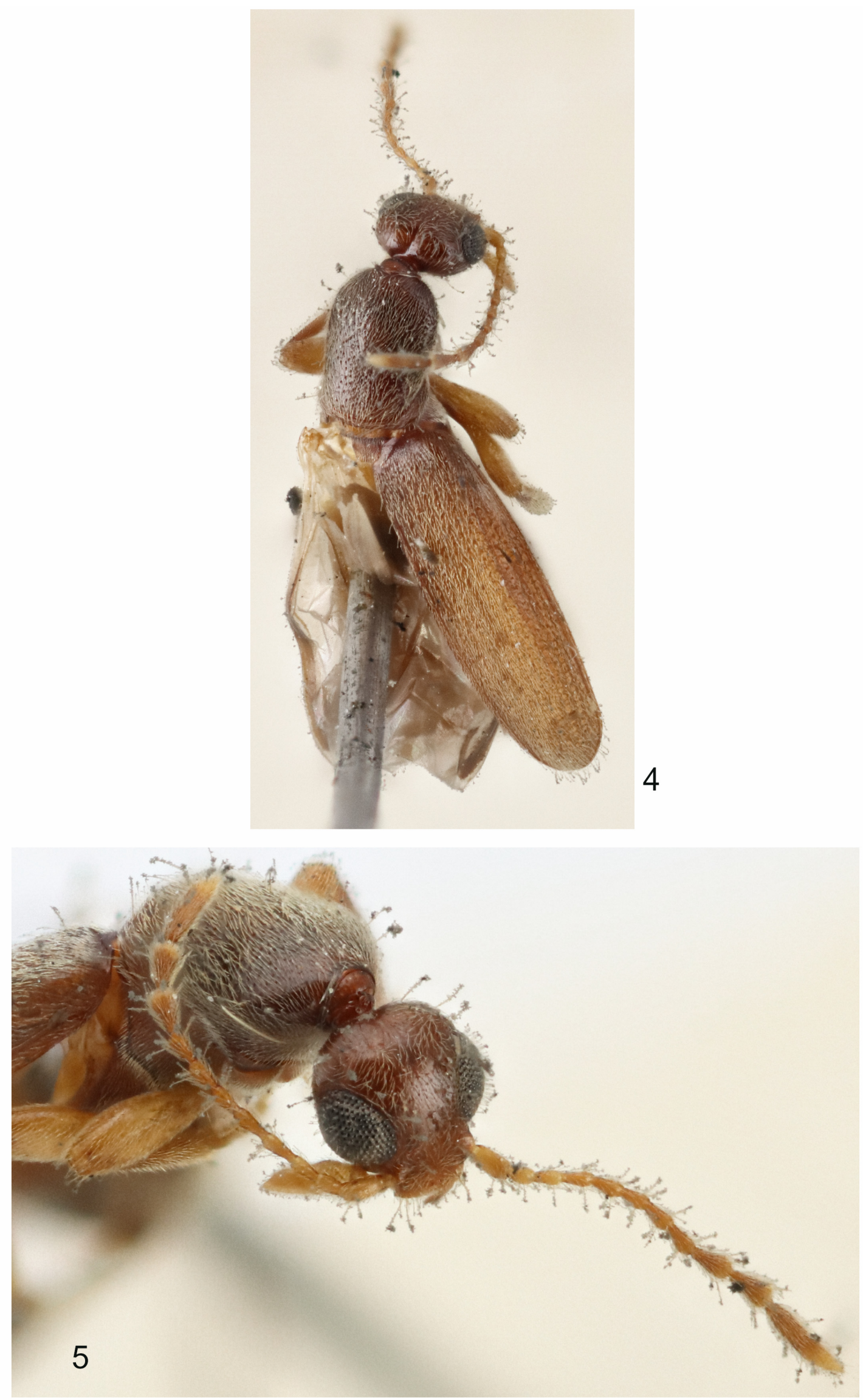

FIGURES 4-5. Macratria fijiana sp. nov., paratype $q$ (BMNH). 4-general view, dorsally, 5-forebody, laterodorsal view. Not to scale. 

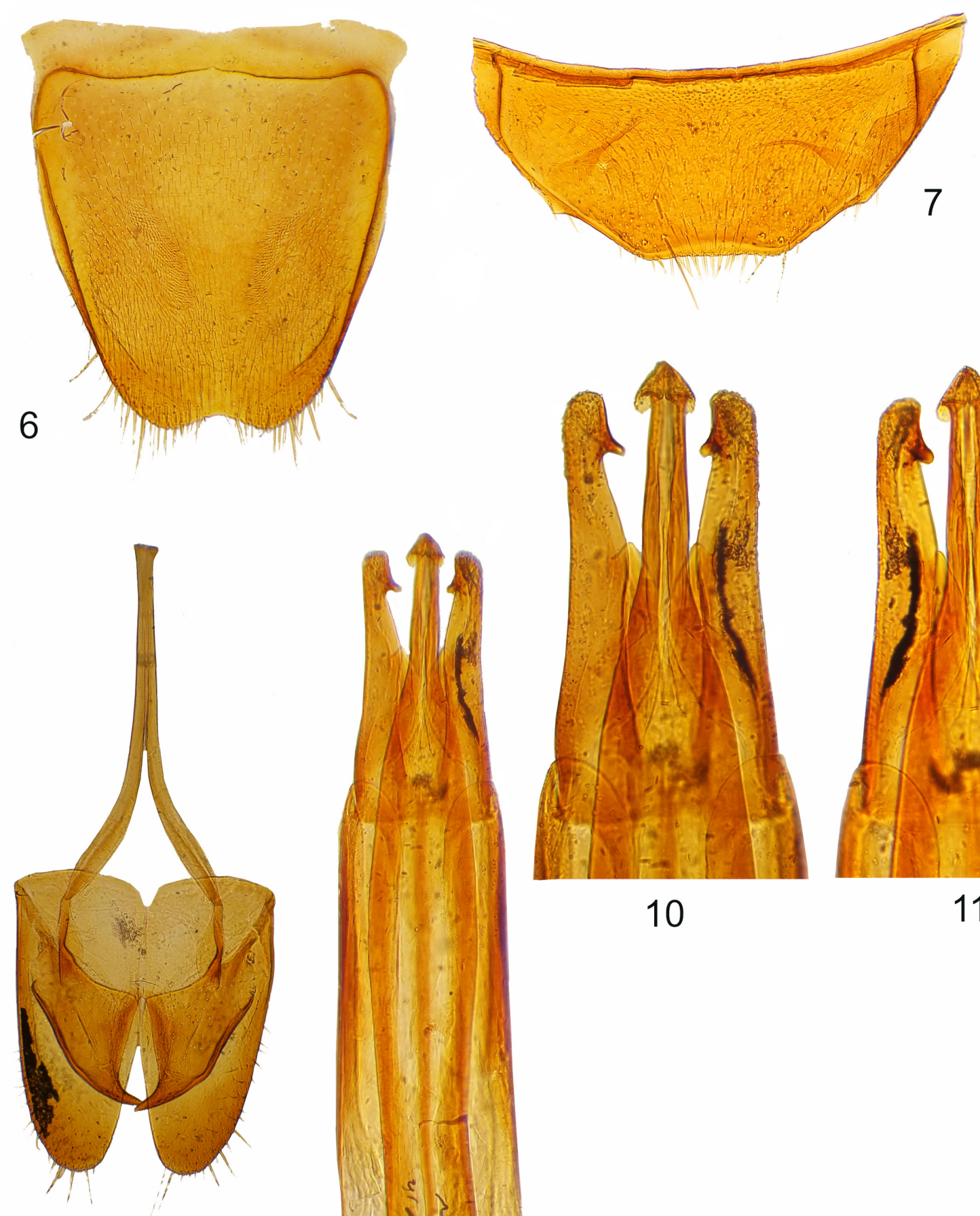

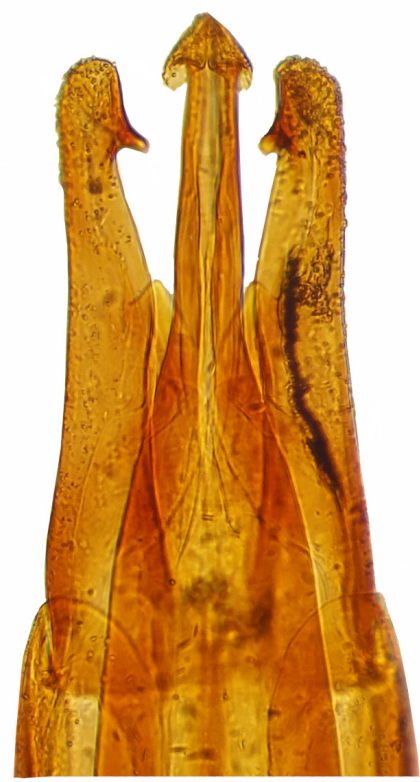

10

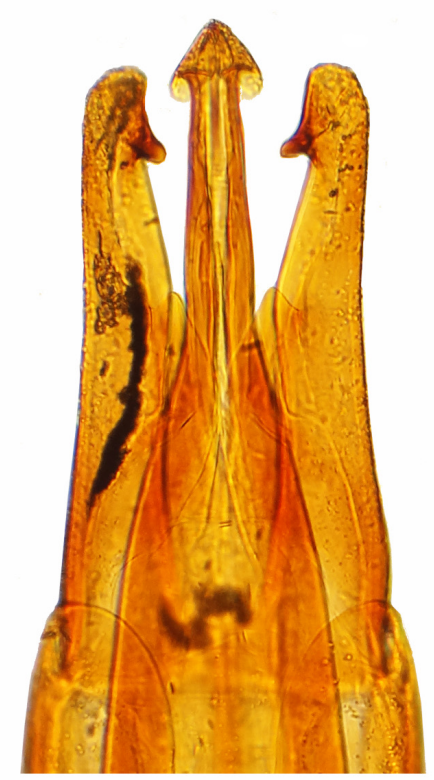

11

8

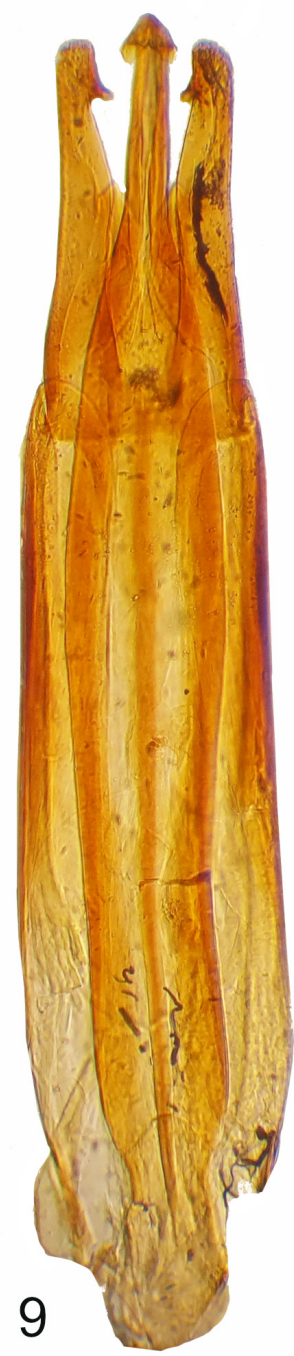

FIGURES 6-11. Macratria fijiana sp. nov., holotype đิ. 6-tergite VII, dorsal view, 7-morphological sternite VII, ventral view, 8-morphological sternites VIII and IX, tergite VIII (on a background), ventral view; 9-aedeagus; 10-11 apical portion of aedeagus, ventral and dorsal view. Not to scale. 
combined length of remaining tarsomeres, in female - same long as combined length of remaining tarsomeres. Male tergite VII broadly emarginate at posterior margin (Fig. 6), sternite VII subtruncate and irregularly microtuberculate at posterior margin (Fig. 7). Female tergite VII and sternite VII broadly rounded at posterior margin. Sternites VIII-IX and tergite VIII as in Fig. 8. Aedeagus with parameres dentate subapically on inner margin (Figs 9-11). Median lobe longer than parameres, tripartite apically, with triangular "cap" covering the apex (Figs 10-11).

Sexual dimorphism. Female terminal antennomere and basal metatarsomere significantly less elongate than in male, terminalia rounded at posterior margin (not as in male).

Differential diagnosis. Macratria fijiana sp. nov. is readily differentiated from all congeners by the shape of the male terminalia and genitalia, particularly the aedeagus.

Etymology. Toponymic. Named after Fiji, the country of origin.

Distribution. Only known from Viti Levu Island, Central Division, Fiji Archipelago (Fig. 12).

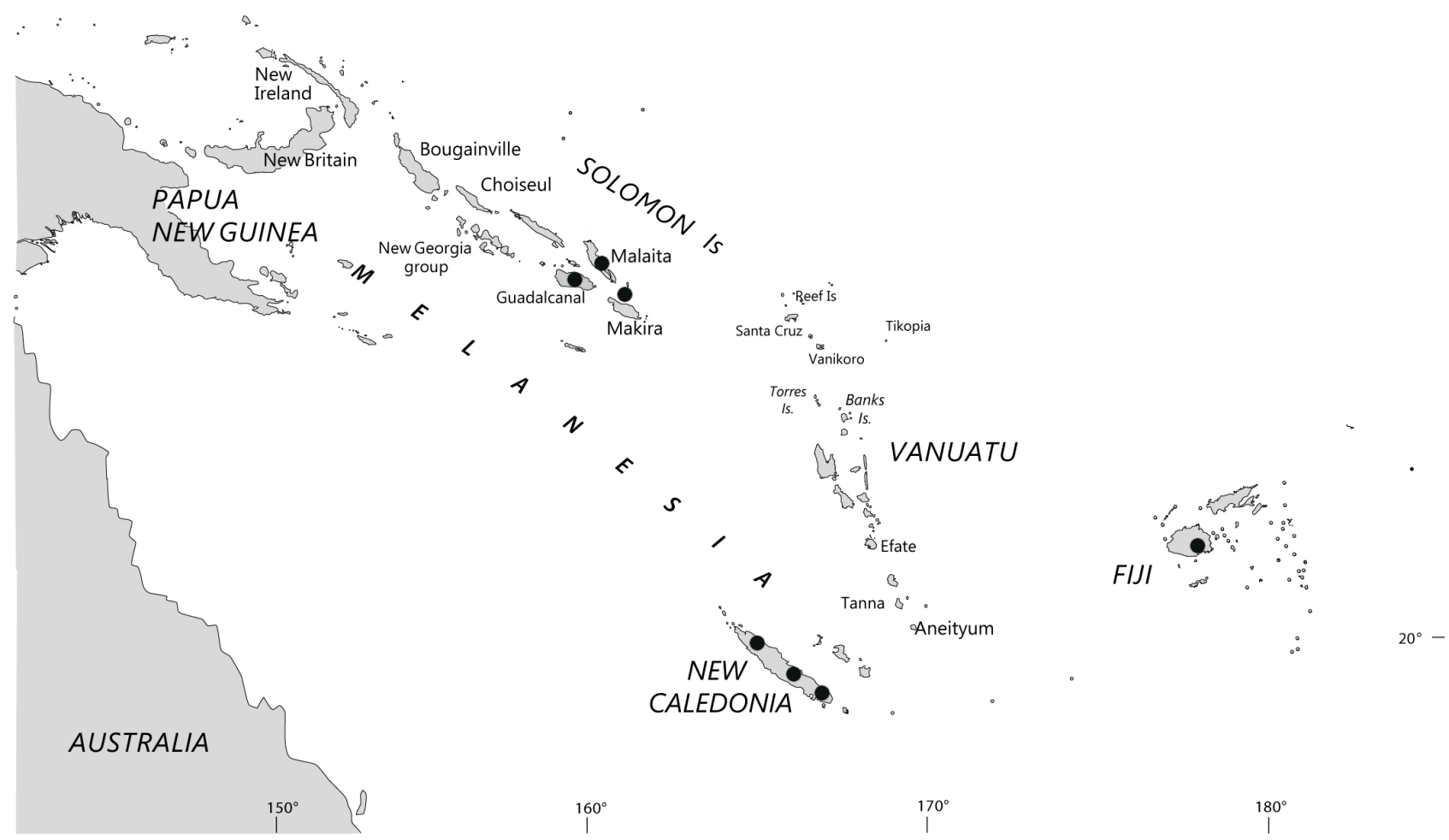

FIGURE 12. Map of Melanesia with schematic distribution of Macratria fijiana sp. nov. (on Fiji) and nearest Macratria records on New Caledonia and the Solomon Islands.

Note. Lever, R. J. A. W., was an applied entomologist based in Fiji and published on entomology and biogeography of Fiji and New Caledonia (Evenhuis 2008). The Macratria fijiana sp. nov. specimens came to the BMNH after the closure of the Commonwealth Institute Collection. The codes " 1928 " and " 1228 " on the original labels of holotype and paratype probably refer to sample numbers / crops / fields or land near fields, but no records for what exactly they mean are available (M. Barclay, personal communication).

\section{New genus-rank synonymy}

\section{Material examined}

Salimuzzamania uniformis (Champion, 1890), holotype 9 BMNH (Fig. 13; habitus image published for the first time): S. Geronimo, Guatemala. Champion. [printed] / B.C.A. Coll.IV.2. Eurygenius [printed] uniformis [handwritten] Champ. [printed] / Sp. figured. [printed] / Eurygenius uniformis ${ }^{\dagger} \mathrm{Ch}$. [handwritten; sic! this specimen is a female] / 527. . . [handwritten] / Type H.T. [printed, label circular, red frame] [current name of the type locality is San Jerónimo]. 
Thambospasta howdeni Werner, 1974, holotype đ̊ CNCI: Big Bend N.P., TEX. 1850’ Boquillas May [printed] 23 [handwritten] 1959. Light Howden \& Becker [printed] / HOLOTYPE $\widehat{\partial}$ Thambospasta howdeni Werner [handwritten] / HOLOTYPE [printed, label red] / HOLOTYPE CNC No. [printed] 15202 [handwritten] [label red] / CNC 943163 [printed, blue frame].

Abdullah (1968: 188) erected Salimuzzamania from a female holotype of Eurygenius uniformis Champion, 1890 (Fig. 13) from Guatemala and originally designated it as the type species of the genus. Salimuzzamania was originally placed by Abdullah (1968) in Eurygeniinae LeConte, 1862 in the family Anthicidae, and remained monotypic. This species also reported from Costa Rica (Lawrence 2001) but without proper locality information.

Werner (1974: 148) erected Thambospasta for a series of T. howdeni Werner, 1974 male and female specimens from Texas, U.S.A., that was originally designated as the type species of the genus. Thambospasta was originally placed in Meloidae "possibly assignable to the subfamily Eleticinae" (Werner 1974) and remained monotypic.

Chandler (2002: 551) placed the genus Thambospasta in the subfamily Eurygeniinae. Telnov (2009, Table 1) compared the morphology of the tarsal claws in Eurygeniinae, Steropinae Jacquelin du Val, 1863 and Macratriinae, and consequently listed Salimuzzamania in Eurygeniinae. Later, Chandler (2010: 730) placed both Salimuzzamania and Thambospasta within Macratriinae and Telnov $(2011 ; 2012 a)$ consequently followed this system.

Some critical features of Salimuzzamania are as follows (modified from Werner (1974)): head is well-differentiated from narrow cranial neck; compound eye broadly and shallowly excavate at anterior margin; vague impression present at place of frontoclypeal suture; outer margin of mandible concave in basal part; mandible apex scooped, mandible unidentate; terminal maxillary palpomere narrowly securiform; procoxal cavities open externally, closed internally; mesanepisterna narrowly meeting in front of mesoventrite, line of fusion poorly indicated; mesoventrite very broadly triangular, obtuse-angled to near-rounded apically; sternite III excavated and margined to receive the metacoxae; metathoracic wing with vein $2 \mathrm{~A}_{2}$ present, connected by a crossvein with $1 \mathrm{~A}$; base of vein $2 \mathrm{~A}_{2}$ well-developed, forming a closed cell; vein $3 \mathrm{~A}_{1}$ connected to base of vein $3 \mathrm{~A}$; crossvein $\mathrm{r}$ present, radial cell is closed; tarsal claws appendiculate, each with an obtuse basal tooth; at least pro- and mesotarsal claws additionally each with a pointed, acute tooth; tibial terminal spurs microspinose; female gonostyli uni-segmented; female sternite VIII anteriorly with a long apodeme.

The two genera Salimuzzamania and Thambospasta are morphologically identical, and the new synonymy proposed here is based on study of the type species of both genera.

Salimuzzamania Abdullah, 1968 = Thambospasta Werner, 1974 syn. nov.

Consequently, the new combination is made for Salimuzzamania howdeni (Werner, 1974) comb. nov.

\section{Discussion}

As of Telnov (2011), the easternmost previously known records of Macratriinae and Macratria in Melanesia were from Uki (Uki Ni Massi) Island North of San Cristobal (about $161^{\circ} 42-44^{\prime}$ E), eastern Solomon Islands, from where M. nguzunguzu Telnov, 2011 was recently described, and from Grande Terre of New Caledonia, where M. caledonica Fauvel, 1906, M. lipsbergi Telnov, 2019, M. manfredjaechi Telnov, 2019 and M. rectipilis Telnov, 2012 occur. Of New Caledonian species, M. caledonica (about $166^{\circ} 40^{\prime} \mathrm{E}$ ) and M. manfredjaechi $\left(166^{\circ} 40^{\prime} \mathrm{E}\right)$ are already recorded from the SE tip of the island, but for M. lipsbergi only one record from the type locality in northern Grande Terre was known (Telnov 2019), until the following recent material from central part of the island became accessible: New Caledonia, Pr. Sud 3 km NW Sarramea S 2137', E 16550’ 23.-30.12.2011 250-550 m a. Kudrna Jr. lgt. (2 specimens, DTC). In the southern Pacific, the easternmost record of Macratriinae known is for M. exilis Pascoe, 1877 from the eastern peninsula of the Northern Island, nearly $178^{\circ} 0^{\prime} \mathrm{E}$ (Werner \& Chandler 1995).

The Fijian record of Macratria fijiana sp. nov. from Naduruloulou is from about $178^{\circ} 31^{\prime} \mathrm{E}$, while the record from Karova (= Karovou) - from about $178^{\circ} 20^{\prime} \mathrm{E}$, making them the easternmost known records of the Macratriinae and Macratria. Uki Island of the Solomons (Macratria nguzunguzu type locality) is located about $2000 \mathrm{~km} \mathrm{WNW}$ and S Grande Terre (locality for M. caledonica and M. manfredjaechi) is about $1315 \mathrm{~km} \mathrm{SW}$ of the localities for 
Macratria fijiana sp. nov. The new species is not closely related morphologically to any of the currently known New Caledonian Macratria nor to the Solomon Islands species. No Macratriinae records are presently known from Vanuatu, an archipelago between Fiji and the Solomon Islands / New Caledonia. The route by which Macratria colonised Fiji therefore remains obscure.

The two species, Salimuzzamania uniformis and S. howdeni are both considered good species, but the male is unknown for $S$. uniformis and so comparison of genital characters is not yet possible. Head base is rounded and slightly notched medially in $S$. howdeni but slightly concave medially, nearly subtruncate in S. uniformis (Fig. 13), punctures on dorsal forebody are comparatively smaller and less coarse in $S$. uniformis compared to those in $S$. howdeni, pronotum comparatively shorter, lateral margins of pronotum not emarginate in basal half in $S$. howdeni but somewhat broadly emarginate in S. uniformis (Fig. 13).

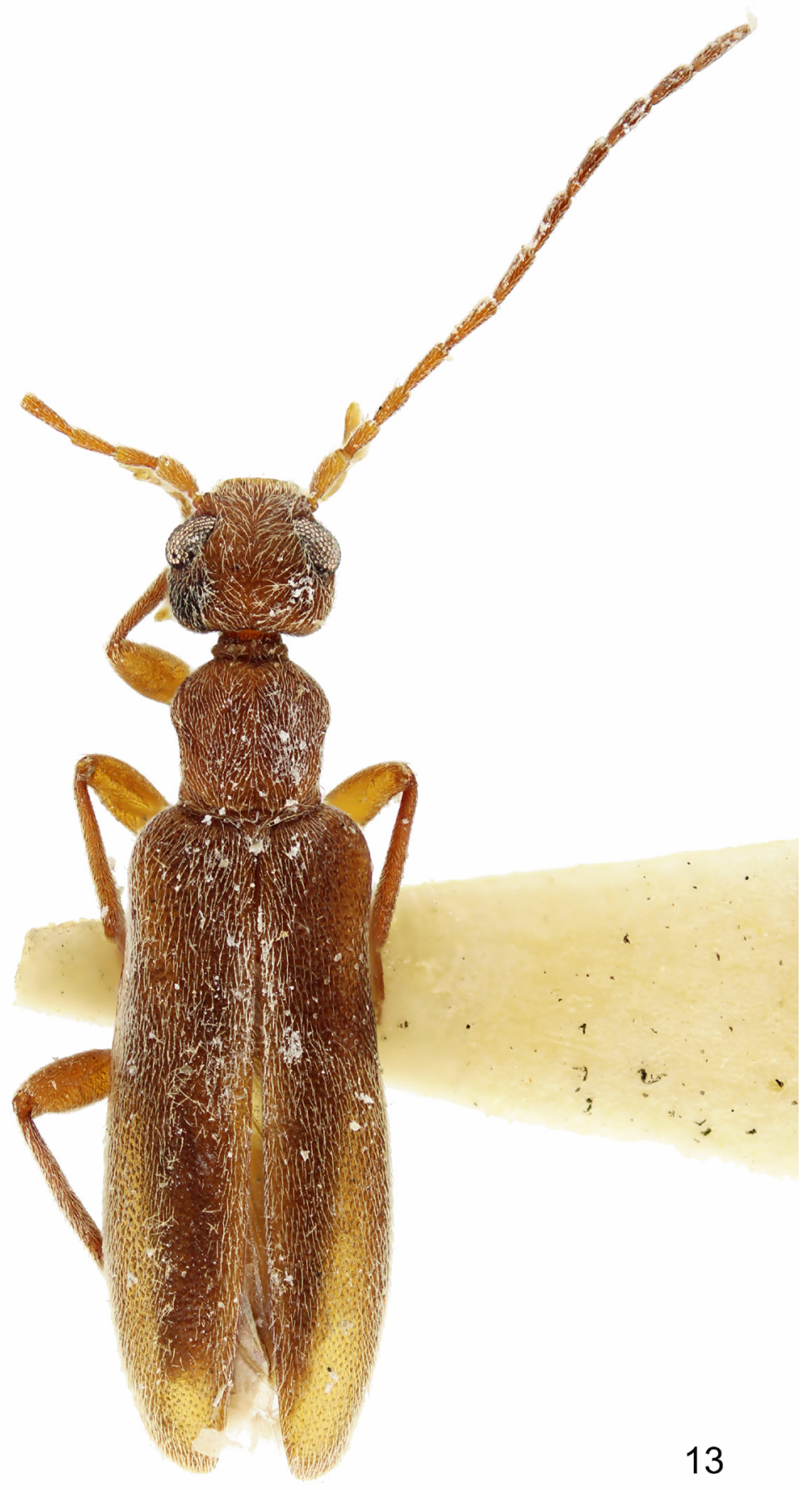

FIGURE 13. Salimuzzamania uniformis (Champion, 1890), holotype $q$ (BMNH), general view, dorsally. 
The type localities of the two species, in Guatemala and southern Texas, are separated by more than $2200 \mathrm{~km}$, but this is not considered peculiar. About a third of the Anthicidae sensu stricto genera in the Americas have wide distributions. Of a total of 47 American anthicid genera, 14 are found in both Nearctic and Neotropical regions (incertae sedis genera as of Lawrence et al. (2010) and Telnov \& Degiovanni (2021), as well as Hirticomus Pic, 1894, Omonadus Mulsant et Rey, 1866, and Stricticomus Pic, 1894 represented in the Americas only by non-autochthonous species are not considered; Salimuzzamania and Thambospasta are here considered single genus). This is true for both large, species-rich genera (for instance, Macratria Newman, 1838, Notoxus Geoffroy, 1762, Sapintus Casey, 1895, Tomoderus LaFerté-Sénectère, 1849, all with cosmopolitan distribution) as well as for less diverse and the Americas-restricted groups (for instance, Bactrocerus LeConte, 1866, Eurygenius LaFerté-Sénectère, 1849, Rilettius Abdullah, 1964, Squamanotoxus Chandler, 2001).

\section{Acknowledgements}

Sulu Daunivalu (Rīga, Latvia) thanked for valuable comments on type localities of the new species. Special thanks to Maxwell V. L. Barclay (BMNH) for proofreading the manuscript and valuable comments on the origin of discussed Fijian material in the BMNH collection.

\section{References}

Abdullah, M. (1968) Salimuzzamania uniformis (Champion) gen. n. et sp. comb. nov. (Coleoptera: Anthicidae, Eurygeniinae) from Guatemala. Pakistan Journal of Scientific and Industrial Research, 11 (2), 188-189.

Chandler, D.S. (2002) 117. Anthicidae Latreille 1819. In: Arnett, R.H., Thomas, M.C., Skelley, P.E. \& Frank, J.H. (Eds.), American Beetles. Vol. 2. Polyphaga: Scarabaeoidea through Curculionoidea. CRC Press, Boca Raton, London, New York and Washington, D.C., pp. 549-558.

Chandler, D.S. (2010) 11.26. Anthicidae Latreille, 1819. In: Leschen, R.A.B., Beutel, R.G. \& Lawrence, J.F. (Eds.), Coleoptera, Beetles. Vol. 2. Morphology and systematics (Elateroidea, Bostrichiformia, Cucujiformia partim). Arthropoda Insecta. Handbook of Zoology. De Gruyter, Berlin \& New York, pp. 729-741. https://doi.org/10.1515/9783110911213.729

D’Urville, D.M.J. (1832) Notice sur les Iles du Grand-Océan. In: D’Urville, D.M.J. (Ed.), Voyage de la corvette l'Astrolabe exécuté par Ordre du Roi, pendant les années 1826-1827-1828-1829, sous le commandement de J. Dumont d'Urville, capitaine de vaisseau, philologie par M. d'Urville. J. Tastu, Paris, pp. 611-630.

Evenhuis, N.L. (2008) Fijian terrestrial arthropod bibliography. Second Edition. Bishop Museum Technical Report, 40, 1303.

Green, R. (1991) Near and Remote Oceania: Disestablishing "Melanesia” in culture history. In: Pawley, A. (Ed.), Man and a half: Essays in Pacific Anthropology and Ethnobotany in honour of Ralph Bulmer. The Polynesian Society, Auckland, pp. 491-502.

Kirejtshuk, A. G. \& Azar, D. 2008. New taxa of beetles (Insecta, Coleoptera) from Lebanese amber with evolutionary and systematic comments. Alavesia, 2, 15-46.

Lawrence, J.F. (2001) Las familias de Coleoptera de Costa Rica. INBio. Available from: http://www.inbio.eas.ualberta.ca/papers/coleoptera/ANTHICIN.html (accessed 18 January 2021)

Pawley, A. \& Green, R. (1973) Dating the dispersal of the Oceanic languages. Oceanic Linguistics, 12 (1/2), 1-67. https://doi.org/10.2307/3622852

Lawrence, J.F., Escalona, H. \& Leschen R.A.B. (2010) 11.29. Tenebrionoidea Incertae sedis. In: Leschen, R.A.B., Beutel, R.G. \& Lawrence, J.F. (Eds.), Coleoptera, Beetles. Volume 2: Morphology and Systematics (Elateroidea, Bostrichiformia, Cucujiformia partim). Handbook of Zoology. Arthropoda: Insecta. De Gruyter, Berlin \& New York, pp. 750-760. https://doi.org/10.1515/9783110911213.750

Tcherkézoff, S. (2009) Polynésie/Mélanésie: L'invention française des “races” et des régions de l'Océanie (xvie-xxe siècles). Au vent des îles, Papeete, 376 pp.

Telnov, D. (2009) Review of the genus Telesinus Fairmaire, 1903, with a general discussion on African Eurygeniinae (Coleoptera: Anthicidae). Mitteilungen des Internationalen Entomologischen Vereins e.V., 34 (3/4), 93-113.

Telnov, D. (2011) Taxonomische Revision der Gattung Macratria Newman, 1838 (Coleoptera: Anthicidae: Macratriinae) aus Wallacea, Neuguinea und den Salomonen. In: Telnov, D. (Ed.), Biodiversity, Biogeography and Nature Conservation in Wallacea and New Guinea. Vol. I. The Entomological Society of Latvia, Rîga, pp. 97-285, pls. 17-37. https://doi.org/10.5962/bhl.title.150137

Telnov, D. (2012a) Macratriinae (Coleoptera: Anthicidae) of the Baltic amber. Latvijas Entomologs, 51, $28-40$.

Telnov, D. (2012b) New records and new species of Macratriinae from the Papuan Region (Coleoptera: Anthicidae). Vernate, 
$31,429-468$.

Telnov, D. (2017) New records and new species of Macratriinae from the Papuan Region (Coleoptera: Anthicidae), 2. In: Telnov, D., Barclay, M.V.L. \& Pauwels, O.S.G. (Eds.), Biodiversity, biogeography and nature conservation in Wallacea and New Guinea. Vol. III. The Entomological Society of Latvia, Rîga, pp. 467-494, pls. 94-96.

Telnov, D. (2019) Preliminary account of the Anthicidae (Coleoptera) of New Caledonia. Annales zoologici, 69 (3), $541-559$. https://doi.org/10.3161/00034541ANZ2019.69.3.005

Telnov, D. \& Degiovanni, A. (2021) Review of the Chilean Anthicidae sensu lato (Insecta: Coleoptera), with critical notes on the Lemodinae and Tomoderinae, new descriptions and synonyms. Annales Zoologici, 71 (1), 101-152. https://doi.org/10.3161/00034541ANZ2021.71.1.006

Werner, F.G. (1974) A new genus of primitive Meloidae from West Texas (Coleoptera). Psyche, 81, 147-154. https://doi.org/10.1155/1974/98193

Werner, F.G. \& Chandler, D.S. (1995) Anthicidae (Insecta: Coleoptera). Fauna of New Zealand 34. Manaaki Whenua Press, Lincoln, Canterbury, 64 pp. 